\title{
Lethal Laws and Lethal Education: A Case Study of Soviet Genocide Against Polish Foresters and Five Decades of Infodemic
}

\author{
Dariusz J. Gwiazdowicz ${ }^{1} \cdot$ Aleksandra Matulewska² $^{2}$
}

Published online: 17 August 2020

(c) The Author(s) 2020

\begin{abstract}
Genocide as a part of nation or ethnic group extermination process is not a welldefined concept. Its meaning is understood intuitively. When law intervenes, the issue of defining the term comes back. Nevertheless, the Polish nation has been recognized as subjected to genocide activities during the Second World War by the Nazi Germany and Soviet Union. The paper focuses on the genocide against mainly one group of Poles that is to say foresters. The martyrologic evidence proves that foresters were an occupation group which for a variety of reasons suffered most. The research carried out in this respect by the National Forests in Poland has revealed that over $20 \%$ of pre-war staff of the institution actually lost their lives. They were killed by the German and Soviet occupiers, as well as the Ukrainian Insurgent Army. ${ }^{1}$ In the eastern parts of Poland foresters and their families were deported and sent to various labour and extermination camps e.g. in Siberia. The aim of the paper is to present the scale of genocide with the main emphasis on genocide against foresters. The definition of genocide provided by Lemkin (Axis rule in occupied Europe: laws of occupation, analysis of government, proposals for redress, Carnegie Endowment for International Peace Division of International Law, Columbia University Press, Washington, DC, New York, 79-95, 1994), who coined the term, is a starting point for the analysis. The main research methods included the analysis of pertinent literature and source materials as well as the semiotic analysis of genocide circumstances. The thesis put forward by the authors is that foresters due to their education, practical skills, professional experience and insight knowledge turned out to be the group especially vulnerable and subjected to extermination on purpose.
\end{abstract}

Keywords Genocide - Genocide of foresters · Extermination of professionals · Genocide and law $\cdot$ Fake news $\cdot$ Infodemic $\cdot$ Language of propaganda

\footnotetext{
${ }^{1}$ https://www.lasy.gov.pl/pl/wideo/telewizja-lasow-panstwowych/wideo/martyrologia-lesnikow-Katyńsybir-kresy.

Aleksandra Matulewska aleksmat@amu.edu.pl

Extended author information available on the last page of the article
} 


\section{Introduction}

The aim of the paper is to focus on the genocide of foresters as a part of nation or ethnic group extermination process carried out in the light of laws and covered by political propaganda infodemic lasting for five decades. The concept of genocide is far from being well defined, though it was used for the first time by Lemkin [18]. The meaning of genocide, similarly as extermination, is understood intuitively. The meaning of the term is important when discussing it in legal settings. Once the instances of genocide are revealed to public, frequently as a result of declassification of top secret files, the problem of acknowledging the crimes as instances of genocide occurs. When law intervenes, the issue of defining those terms comes back. The instances of repressions discussed in that paper have actually been classified as genocide.

On August 23, 1939, the Third Reich and the USSR signed an international agreement, which was formally a non-aggression pact. Pursuant to a secret additional protocol, constituting an annex to the official document of the agreement, the independence of sovereign states, including Poland, was established. This agreement, commonly known as the Molotov-Ribbentrop Pact, opened up the possibility of armed aggression. On September 1, 1939, without declaring war, the Polish territory was invaded from the west by German troops. In turn, on September 17, 1939, Soviet troops attacked from the east.

The repressions concerned the entire community of Poles, but there were also professional groups that suffered particularly. The occupants wanted to erase Polishness, so they began with the repression of the intelligentsia, e.g. university employees, teachers, priests, lawyers, landowners, etc. One of the persecuted groups included also foresters, who were educated and held high positions as civil servants. In addition, they had military training, the ability to use hunting weapons, they knew the topography well and were a potential threat as partisans.

The Polish nation has been recognized as subjected to genocide activities during the Second World War by the Nazi Germany and Soviet Union. Nevertheless, the in-depth analysis of social groups that were victims of genocide is not usually touched upon. The aim of the paper is to investigate whether one professional group, that is to say foresters, were subjected to Soviet genocide acts because of their specific professional profile or in general as a group belonging to the so-called intelligentsia and what sort of legal basis was used to carry out the annihilation operations. The martyrologic evidence [20] proves that foresters were an occupation group which for a variety of reasons suffered most. Revealing the reasons for their persecution and extermination thus seems justified. The analysis takes into account the legal basis for cleansing actions, political propaganda used to cover the crime which in fact may be classified as infodemic and social factors that actually made the group under scrutiny especially vulnerable. Furthermore, the authors focus on the genocide operations of the former USSR. The thesis which is put forward by the authors is that foresters due to their education, practical skills, professional experience and insight knowledge turned out to be the group especially vulnerable and subjected to extermination on purpose. 
The second part of the paper is devoted to the Katyn infodemic and efforts to counter-act it.

\section{Research Methods and Materials}

The main research method included the analysis of pertinent literature and source materials. The source materials included the legal bases issued by the former USSR to carry out cleansing operations, memoires of survivors, cemetery books and other archival material including press releases and history books.

The research methods encompass the semiotic analysis of circumstances leading to atrocities which takes into account the following semiotic background: (1) genocide legal bases and mode of their expression, (2) language of propaganda and infodemic, (3) social factors making the foresters especially vulnerable to genocide.

\section{Definition of Genocide}

The term genocide was coined by a Polish professor of law, Lemkin [18] as a combination of the Greek genos meaning 'race or tribe' and the Latin cide meaning 'killing'. He actually distinguished eight aspects of genocide: physical (being the most visible - the physical deprivation of life), but also political, social, cultural, economic, biological, religious, and moral. All those aspects lead to the eradication of a group of people, their resources and heritage.

Political genocide encompassed according to Lamkin destroying local self-governments, imposing the administrative structures of the occupying nation, replacing all sorts of signs in public space with ones formulated in the occupying nation's language. In Poland it was clearly visible everywhere as names of streets, cities and buildings were changed again after a short period of independence from 1918 till 1939 [18: 79-95].

The social dimension of genocide was understood by Lemkin as the liquidation of local courts and law and replacing them with the occupying nation's judicial system. Such changes weaken the society and are mostly aimed at limiting the participation of intelligentsia in vital spheres of social life [18: 79-95].

The cultural genocide involved eradicating the native language from public life and strictly controlling and censoring the activities of journalists and artists engaged in painting, drawing, sculpture, music, literature, and the theater. It also involved stealing and destroying works of art such as books, paintings, sculptures, etc. It also encompassed destroying archives [18: 79-95]. The bombing of Warsaw in which state and church archives were destroyed was an example of such cultural genocide [18: 79-95, cf also 49].

The economic genocide involves the deterioration of the standard of living, limiting jobs and salaries, introducing conditions in which the need of physical survival makes people abandon other spheres of life (going to theaters, buying books, etc.) [18: 79-95]. 
The biological genocide involved the depopulation of the nation by decreasing birth rates of one nation and increasing the birth rates of another, dominant nation [18: 79-95].

The physical genocide involved all sorts of measures leading to the extermination of the nation starting from rationing food, through limiting access to medicaments, blankets, other priority commodities and ending with killings including atrocities of mass killings [18: 79-95].

The religious genocide included limiting access to religious practices by destroying churches, persecuting clergymen, indoctrination [18: 79-95].

The moral genocide was understood as encouraging degeneration of the nation. Lemkin claims that according to the plan

\begin{abstract}
"the mental energy of the group should be concentrated upon base instincts and should be diverted from moral and national thinking. It is important for the realization of such a plan that the desire for cheap individual pleasure be substituted for the desire for collective feelings and ideals based upon a higher morality. Therefore, the occupant made an effort in Poland to impose upon the Poles pornographic publications and movies. The consumption of alcohol was encouraged, for while food prices have soared, the Germans have kept down the price of alcohol, and the peasants are compelled by the authorities to take spirits in pay agricultural produce. The curfew law, enforced very strictly against Poles is relaxed if they can show the authorities a ticket to one of the gambling houses which the Germans have allowed to come into existence" (Lemkin 1994, 90).
\end{abstract}

As we can see from the juxtaposition presented above genocide is a very broad concept which may be interpreted taking into account a wide variety of factors affecting a group of people and their lives. What is more, genocide may not be the act of physical killing but depriving a group of people of the ability to function normally developing all their needs.

\title{
4 Social Factors and Legal Background
}

\subsection{A Lethal Profession}

Polish foresters actually went through all genocide dimensions. They were executed as prisoners of war (which constituted the breach on international conventions), sent to labour camps or deported with their families. The research carried out in this respect by the National Forests in Poland revealed that over $20 \%$ of pre-war staff of the institution actually lost their lives. They were killed by the Soviet occupiers, as well as Ukrainian nationalists from Ukrainian Insurgent Army [20].

There are numerous reasons that actually made foresters the vulnerable group subjected to various types of extermination. One of them was their professional and military education, training and knowledge that made them dangerous opponents in war. 


\subsection{How Many Educated Foresters were in the Interwar Period in Poland?}

Until 1918, Poland was not on the map of Europe and some foresters studied at the Royal Saxon Academy of Forestry (Königliche-Sächsische Forstakademie) in Tharandt and the Hochschule für Bodenkultur in Vienna. Analyzing the data presented by Chałupka and Modrzyński [6] it can be assumed that several dozen graduates of these universities worked in forestry in the interwar period. Some of them graduated from the National School of Forest Management in Lviv (from 1874), but it did not have the status of a university.

After regaining independence in 1918, the situation changed dramatically, because a forestry education system was created. It included three universities in the cities of Warsaw, Lviv and Poznań, where studies lasted 4 years. In the interwar period, these universities issued 2124 diplomas of forestry engineer: at the Warsaw University of Life Sciences (SGGW—Szkoła Główna Gospodarstwa Wiejskiego) in Warsaw-809, at the University of Poznań-652, at the Lviv Polytechnic_-663 [16].

According to Molenda [24], 58\% of graduates worked in State Forests, $21 \%$ in private forests, and the rest out of their profession.

In addition, technical staff were educated in three three-grade secondary forest schools (in Białokrynica, Łomża and Żyrowice) and in the interwar period there were about 600 graduates of those schools. Lower forest vocational schools with an 11-month course also operated. There were five such institutions in Poland (in Białowieża, Bolechów, Cieszyn, Margonin and Zagórz) and in the interwar period about 1900 graduates left them [24].

Foresters were employed as civil servants, and the legal basis was the Act on the State Civil Service of February 17, 1922 [39] and the Regulation of the President of the Republic of Poland of 22 March 1928 regarding the amendment of certain provisions of the Act of 17 February 1922 on the state civil service [45]. The rules for employing "forest officials" in various positions, education requirements, scope of the vocational examination, salary categories, etc. were regulated by Regulations of the Council of Ministers [40, 41, 42, 43, 44, 47, 48] and the Regulations of the Minister of Agriculture [38, 37, 46]. Analyzing these legal acts, it can be stated that at all levels of employment in the State Forests one had to demonstrate vocational education and pass the exam. In order to become a director or a forest inspector, one had to have a higher education, a forestry secondary education, and a gamekeeper's post training course. It can therefore be concluded that in Poland, in the interwar period, foresters belonged to the intellectual elite.

\subsection{How Many Foresters Worked in the Territory Occupied by Soviets in 1939?}

In the interwar period, 9 Directorates of State Forests operated in Poland. After the occupation of part of Poland by the USSR, three directorates in full (Białowieża, Łuck, Vilnius) and two in part (Lviv, Siedlce) were under the Soviet influence. It was nearly 200 forest districts and about 750 forestries [3]. It can be assumed that in each forest inspectorate there was employed one forest inspector, and each forestry 
was supervised by one forester and several gamekeepers (from 4 to 7). Analyzing the employment data in the directorate in Siedlce, it is known that in 1939 all foresters (31 forest districts) had higher education, while most foresters and office workers, and some for gamekeepers had secondary education [36]. There were definitely fewer foresters employed in private forests than in state ones.

However, the number of foresters living in the east territories at the end of September 1939 was higher because after the German invasion many foresters, especially high-level ones fled to the east.

The story illustrating that state of affairs may be the fate of the Director of the State Forests Directorate Headquarters (Naczelna Dyrekcja Lasów PaństwowychNDLP) Adam Loret. At the beginning of September 1939 Warsaw was bombed by the Luftwaffe, and German troops approached the Polish capital. Director Loret, along with high-level NDLP officials and the most important documents left Warsaw moving east. They did not expect, however, that on September 17, 1939, without declaring a war, the Soviet army would enter the territories of Poland. The Red Army arrested them. Adam Loret was murdered, and the circumstances of his death were not fully explained [11]. Russian archive materials regarding this matter have not been released so far.

\subsection{How Many Foresters were Murdered by the Soviet Regime?}

There is no access to many documents deposited in the Soviet archives. Furthermore, some of the documents were destroyed for sure. From what has been confirmed, 810 foresters from the eastern lands were murdered, of which 193 in Katyń massacre. In addition, about 70 were deported to labour camps and about 600 deported deep into the USSR. These data do not include forestry family members. The rule was that high-level (educated) foresters were murdered, and low-level ones, e.g. gamekeepers, i.e. people after short training, were transported as workers for work in the forest.

\subsubsection{Semiotic Analysis of Factors Contributing to the Genocide of Foresters}

Considering how many foresters worked in the eastern directorates of State Forests in 1939, and how many died or were affected by other consequences (e.g. deportations), it can be argued that this was a professional group that particularly suffered from the cruelty of Soviet aggression (Figs. 1, 2).

\subsubsection{Katyń Genocides Committed on Foresters}

The assessments made on the basis of cemetery books in which the people buried were registered reveals that:

1. 69 foresters are registered as buried in Katyń cemetery books,

2. 60 foresters are registered as buried in Kharkov cemetery books,

3. 9 foresters are registered as buried in Miednoye cemetery books, 


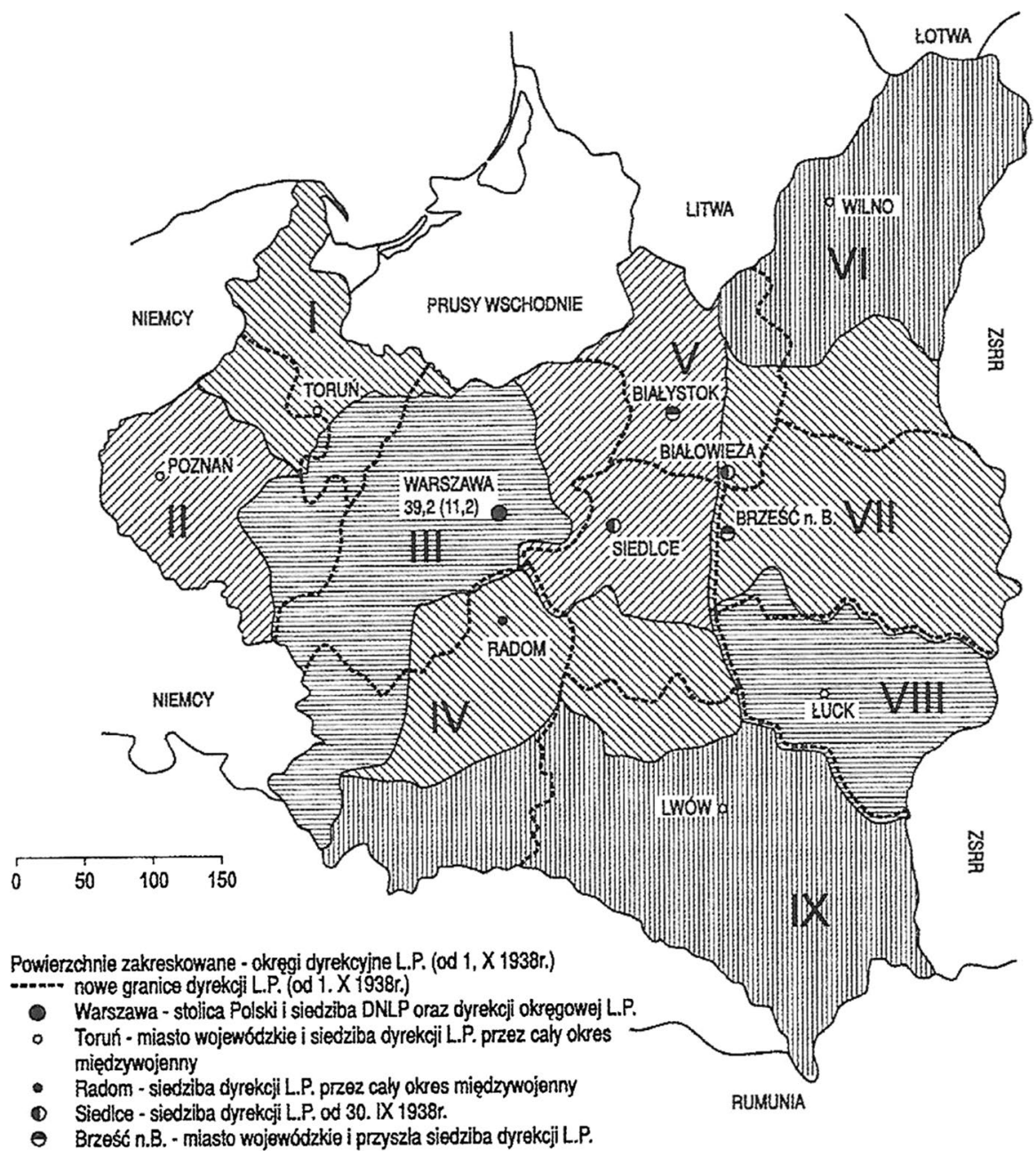

Fig. 1 The territory of Poland divided into districts of the State Forests in 1938 [3]

4. 32 foresters are registered as buried in Kiev-Bykovnia cemetery books,

5. 20 foresters are registered as buried in Minsk-Kuropaty cemetery books [28: $120-136,7]$.

As no sufficient data is provided in short biographical notes of victims who died in Minsk-Kuropaty that group will not be included in the statistics provided below. The analysis of educational profile of victims of Katyń genocides who were employed in the interwar period in the forest industry reveals that:

1. almost all of them held positions with some responsibility and the majority of them had at least vocational secondary education; 


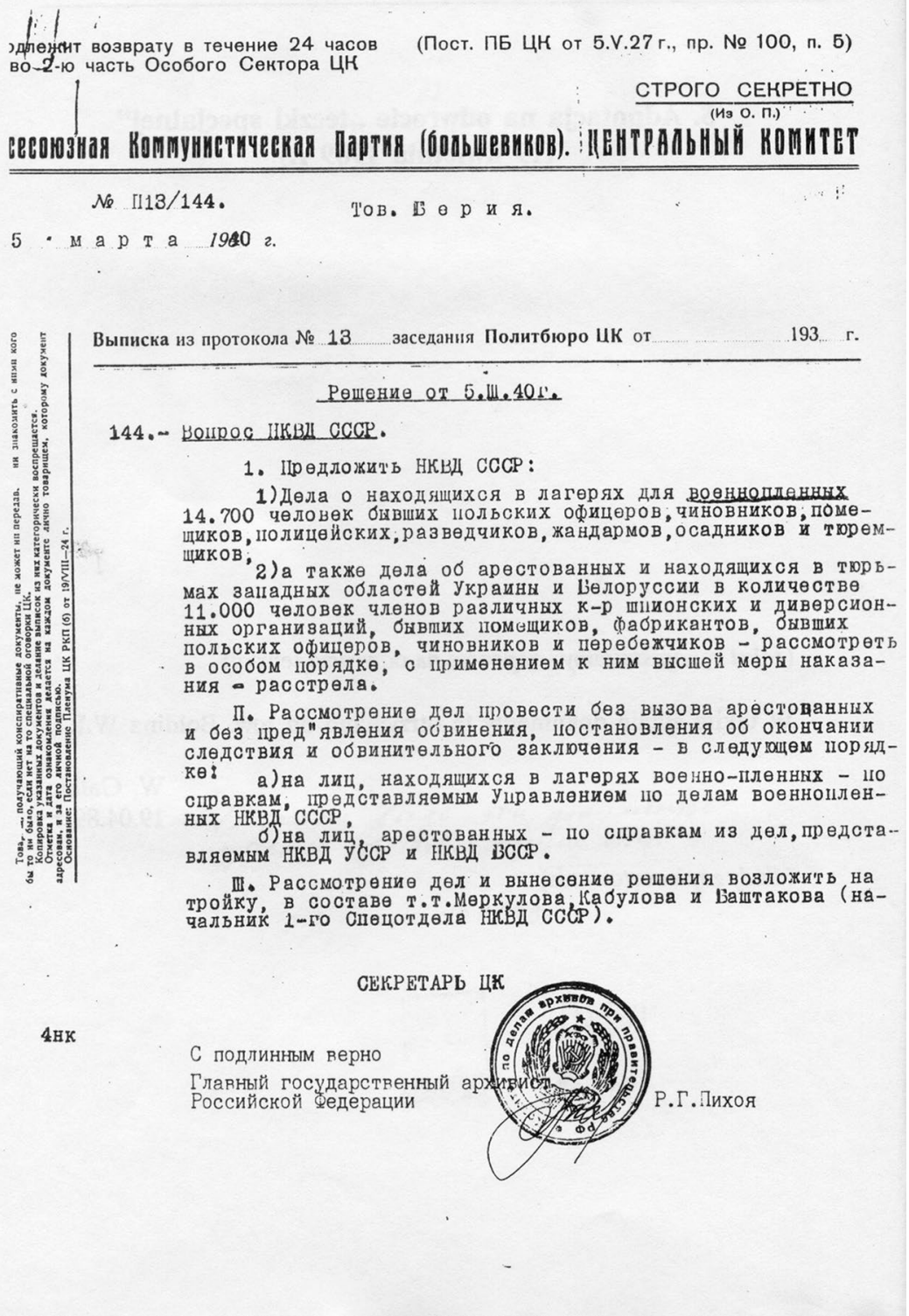

Fig. 2 The decision on the murder of Polish prisoners of war and prisoners: the Order for the NKVD of the USSR, Moscow top secret document of March 51940 
Table 1 Juxtaposition of educational profile of foresters killed in Katyń genocides

\begin{tabular}{lllll}
\hline Number of foresters with: & Katyń & Charkov & Kiev-Bykovina & Mednoye \\
\hline Higher education & 45 & 43 & 18 & 1 \\
Engineer degree & 30 or 31 & 34 & 13 & 1 \\
Secondary education & 65 & 53 or more & 20 or more & No data \\
\hline
\end{tabular}

Table 2 Juxtaposition of the educational profile of 171 foresters who were victims of Katyń genocides

\begin{tabular}{lll}
\hline & $\begin{array}{l}\text { Number of } \\
\text { persons }\end{array}$ & $\begin{array}{l}\text { Percentage with the total num- } \\
\text { ber of 171 foresters being 100\% }\end{array}$ \\
\hline Total number of victims & 171 & $100 \%$ \\
Number of victims with secondary education & 139 & $81.28 \%$ \\
Number of victims with higher education & 107 & $62.57 \%$ \\
Number of engineers & 78 & $45.61 \%$ \\
\hline
\end{tabular}

2. there were at least 45 who had higher education out of which 30 or 31 were engineers (higher education) and 8 persons studied at Universities out of 69 persons registered in Katyń cemetery books; though judging on their positions more of them had at least secondary vocational education (at least 65 had secondary education);

3. there were at least 43 persons with higher education, including 34 engineers (and one engineer qualification pending) and 4 persons studied at Universities out of 60 persons registered in Charkov cemetery books; though judging on their positions most of them had secondary or higher vocational education (at least 53);

4. there were at least 18 who had higher education out of which 13 were engineers (higher education) and 1 person studied at a university out of 33 persons registered in Kiev-Bykovina cemetery books; though judging on their positions more of them had at least secondary vocational education (at least 20 had secondary education);

5. there was at least 1 person with higher education who was an engineer out of 9 persons registered in Mednoye cemetery books; though judging on their positions more of them had at least secondary vocational education.

To sum up, 139 out of 171 had secondary education most probably with graduation exam passed (which constitutes $81.28 \%$ ) out of which 107 graduated from schools of higher education (that is to say 62.57\%), another 13 studied (7.6\%) but they either did not graduate or there is no sufficient data to establish whether they graduated or not. At least 78 out of 107 with higher education $(72.89 \%$ which is $45.61 \%$ of 171 persons registered in the books) were engineers with 2 more possibly being in the course of acquiring the engineering qualifications. (Source: juxtaposition made on the basis of biographical notes provided by Skowronek [28, 29] (Tables 1, 2). 
Table 3 Juxtaposition of educational background of common Polish citizens and foresters murdered in Katyń genocides

\begin{tabular}{lll}
$\begin{array}{l}\text { Common citizens of } \\
\text { Poland }(\%)\end{array}$ & $\begin{array}{l}\text { Common male citizens } \\
\text { of Poland }(\%)\end{array}$ & $\begin{array}{l}\text { Foresters murdered } \\
\text { in Katyń genocides } \\
(\%)\end{array}$ \\
\hline 72.3 & - & 100 \\
4.3 & 4.8 & 81.28 \\
0.7 & 1.2 & 62.57
\end{tabular}

To compare the data with a representative statistics let us provide the educational profile of the average Pole on the basis of the censuses carried out in 1921 and 1931. It should be stressed that the completion of vocational secondary education with the so-called maturity exam passed was at that time considered a very good educational background. In accordance with the last census made in $193172.3 \%$ could read and write. In $19210.7 \%$ of society (males and females altogether) and $1.2 \%$ of males had higher education. $4.3 \%$ of society (males and females altogether) and $4.8 \%$ of males had secondary education. Thus the numbers provided above indicate clearly that the group that was affected by genocide represented the elite of the country [50] (Table 3).

Therefore, it was not only biological and physical genocide but also moral, political and social genocide. Definitely, it was the deprivation of nation of its intelligentsia called by Lemkin the limitation of 'the participation of intelligentsia in vital spheres of social life' not to mention the economic life.

\subsection{Genocide in Gulags}

Sovnarkom on July 11, 1929 issued a secret decree sanctioning the use of penal labour in the so-called Gulags (acronym of Main Administration of Camps, Russian: Главное управление лагерей). The decree constituted the legal foundation of the existence and operation of the system of 'corrective labour camps'. In fact the decree of Sovnarkom was a continuation and formalization of Politburo idea recorded in minutes of 29 June, the same year [27].

After the decree, the so-called Gulag period starts. It lasts from 1930 till 1940. It is characterized by the exploitation of the work of criminal prisoners and the creation of the first series of remand camps. As a result of the transformation of the system, large camps become an essential element of the country's economy. Prisoners become a strategic source of labour. The primary task of gulag system

is to achieve maximum efficiency of prisoners' work. The consistent centralization of management of the penal system was carried out, the culmination of which was in autumn 1934 with the concentration of all places of imprisonment under the auspices of GULAG. Forms of cooperation between the labour and production sectors were actively sought. The evolution of the system of places of imprisonment took place as part of a crystallized cen- 
tralized planned economy, in conditions of intensified struggle at the height of power and conducting massive repressive actions (collectivization, purge of 1937-38). The years 1941-53 were 'the period of the camp and production complex'. Its beginning is associated with the division of the People's Commissariat for Internal Affairs in February 1941 into a security department (NKGB) and a major economic department - NKVD, in whose structure numerous labour and production boards are formed. There are subperiods here: war (June 1941 - fall 1946), reconstruction (end 1946-1948) and the largest expansion (1949 - March 1953). Despite all the shocks caused by the war, a fully formed camp and production complex operates then as one of the most important structures in the economic potential of the state. The distinguishing feature of the period is the full integration of labour and production structures at all levels of the hierarchical system. [25: 58-59].

Between 1937 and 1941 gulags undergo a sort of a reform which leads to economic specialization [1: 141, 25: 58-59]. Some of the forced labour camps start specializing in logging and timber processing. The production in gulags was less efficient than free labour production. Some authors even claim that it was twice less efficient. It is said that it was due to the fact that workers suffered from malnutrition in forced-labour camps. Many of them were political prisoners, not well versed in physical labour. Therefore the influx of professionals in timber production may have been a factor contributing to the numbers of foresters sent to gulags [cf. also 2: 32-86, 34].

Before the outbrake of World War II gulags provided the national economy with $25.3 \%$ of its timber [12].

The majority of foresters and their families were sent to timber production gulags. Some of them were sent to exploit other natural resources in mines. As Broda [2: 91] claims it is not possible to assess how many foresters and their family members lost their lives as a result of deportation to forced labour camps in the territory of USSR. It is due to the fact that there is not even enough data to assess how many people were actually sent to the USSR. There is only a limited number of information on persons who were sentenced to forced labour camps but not those who were taken to distant parts of that country and forced to work for a piece of bread and a bowl of soup. The death toll was high, but again the only historical data that is available includes a limited number of documents and memoirs of persons who survived. People died of exhaustion, malnutrition, diseases, lack of medical help, depression. The majority of them worked in the timber industry [cf. 2: 32-86].

As there is no sufficient data on people who were taken captive and deported, we cannot carry out the analysis of educational profile of foresters that would be representative. Nevertheless the analysis of crimes of which they were accused and for which they were sentenced gives us some insight into their social profile. It frequently happened that they were accused of patriotism, being Polish scouts, serving in the Polish Army during the First World War or the Bolshevik war in 1920 or taking part in various military courses between 1918 and 1939 in the territory of Poland. Some of them were even sentenced as spies solely on the basis of living near the border with the USSR [cf. 2]. 
After the Soviet army occupied the eastern part of Poland, they began to organize their own administrative structures. This also concerned forests constituting a huge area of about 5.5 million ha, where the Soviet forest administration was introduced. According to the accounts of witnesses of those events, representatives of the security service appeared at night and arrested foresters, who were never heard of again (cf. the cited below Directive of the People's Commissar of Internal Affairs of the USSR Lavrenty Beria for People's Commissars of Internal Affairs of the USSR, Ivan Serov and BSRR Lavrenty Canava regarding the deportation to the Kazakh SSR of family members of prisoners of war and prisoners of the People's Commissar of the Interior of the USSR US Commissioner of State Security of 7 March 1940). They were sent either to prison or to labour camps [2]. This situation took place until June 22, 1941, when the German army managed to take over the territories up to then occupied by the USSR.

However, there is no denying the fact that the Polish nation was deprived of highly specialized foresters having vocational secondary and higher education in the field of forestry.

\subsection{Other Reasons for Persecution of Foresters}

\subsubsection{Military Training of Foresters}

At the beginning of the 1930s, the awareness of the threat from the Third Reich and the Soviet Union increased in Poland. It was realized that the army must be supported by the civil service units called the National Defense (Obrona Narodowa$\mathrm{ON}$ ). The training included the acquisition of tactical skills, the use of weapons, as well as sapper training, observation and communication. The border areas had a particularly important role in defending the State. In addition to the Border Guard (Straż Graniczna) and the Border Protection Corps (Korpus Ochrony Pogranicza), counterintelligence structures had to be prepared on the eastern border. The Polish Ministry of Military Affairs rightly believed that foresters who are excellent potential in the state forest service (State Forests) are best suited to this task. Many of them were former soldiers of World War I, participated in various uprisings, e.g. Greater Poland Uprising, and the 1920 war with the Bolsheviks. In addition, after completing their studies, all foresters had to undergo compulsory military service, which most often took place at the Volyn Artillery Reserve Cadet School in Volodymyr-Volynskyi (Wołyńska Szkoła Podchorażych Rezerwy Artylerii we Włodzimierzu Wotyńskim). The legal circumstance enabling the militarization of forest administration employees was the fact that State Forestry foresters were then state officials or civil servants-uniformed officers. Therefore, they were obliged to be ready to defend the country [35].

In 1933, Adam Loret (mentioned above), General Director of State Forests (in the rank of deputy minister), signed with the deputy minister of military affairs division general Tadeusz Kasprzycki an agreement to organize military training of foresters as a part of the established paramilitary organization-Military Adaptation of Foresters (Przysposobienie Wojskowe Leśników-PWL). The purpose of 
this organization was to prepare foresters for the tasks that would be entrusted to them during the war. A particular emphasis was placed on the combat preparation in specific conditions created by the forest and organizing sabotage at the rear of the enemy [4].

The borders of individual PWL districts were in line with the borders of the State Forests Directorates. In administrative terms, the obligation to organize PWL groups and central training centers rested with the directorates of State Forests and individual forest districts or schools for foresters and gamekeepers. Military adaptation of the Foresters began its activity at the end of 1933, pursuant to the statute approved by the Government Commission of the Capital City of Warsaw on November 17 of that year [35].

At the end of the 1930s, PWL trained about 12,000 foresters and forest workers providing a general program. A specialized training program was implemented in larger centers, most often in forestry schools, in the form of 6-week courses organized for this purpose under the guise of general intelligence and counterintelligence training of foresters (among others in Kłobuck-Zagórz near Częstochowa), where the head of such courses was for instance a captain, forest engineer Aleksander Zieliński. Similar courses took place in Margonin near Poznań, where the head of the PWL training was a lieutenant engineer Mieczysław Tarchalski and a second lieutenant engineer Florian Budniak. After completing such courses, foresters were usually directed to forest districts with the task of cooperating with the Border Guard and the Border Protection Corps [35].

Knowledge about military training of foresters was not unknown to aggressors. Even before the attack in September 1939, the USSR strongly developed a spy network and a number of secret communist cells in Poland. Therefore, after the Soviet invasion of Poland, foresters who were more dangerous than representatives of other professions were quickly arrested.

\subsubsection{Partisan Activities}

The professional duties of foresters included running the hunting management, e.g. hunting animals, which is why they had hunting weapons and were well versed in using them (shot very accurately). In addition, they knew the topography of the terrain well, all the "corners of the forest" and had detailed forest maps. This ability to use weapons and good knowledge of the forest meant that they could be helpful in guerrilla warfare.

This is perfectly visible from the analysis of historical materials regarding the areas occupied by soldiers of the Third Reich. One of the first militarized structures was the organization of Józef Gomółka, the forest inspector in the Glinna forest inspectorate. Whereas in the Nagórze Forest District the first military organization of foresters was created under the name Polish Insurgent Association (Polski Zwiazek Powstańczy), similarly in the Meszcze Forest District. Both cells merged within the Union of Armed Struggle (Zwiazek Walki Zbrojnej) in the Tomaszów Mazowiecki region. Another organization was the Consolidation of Defenders of Independence (Konsolidacja Obrońców Niepodległości) founded by forester engineer Kowalewski from the Susiec Forest District [5]. A notable example is also the Secret Military 
Organization "Pomerania Gryphon" (Tajna Organizacja Wojskowa "Gryf Pomorski"), which was the largest independent regional, civilian-military underground organization in Gdańsk Pomerania. Among the members of this organization there were many representatives of the State Forests administration and forestry workers [8].

Outstanding foresters were active in the partisan units, and the examples may be lieutenant Florian Budniak (nickname "Andrzej" [Andrew] or "Borsuk" [Badger]), who was the commander of the "Buk" [Beech] band, which was part of the "Las" [Forest] battalion of the 74th infantry regiment of the Home Army Regiment "Jodła" [Fir] [17]. Another well-known commander of partisan units was the forester Mieczysław Tarchalski (nicknamed "Marcin" [Martin]) fighting in the region of Włoszczowa and Koniecpol [5].

In the areas populated by the USSR, there was no such partisan activity of foresters, as they were quickly exterminated or deported.

In addition, the reluctance or even hostility of the occupiers directed at foresters was caused by the fact that it was the first professional group that documented places of mass executions of people that took place in forests. Something that was carefully hidden, masked by the perpetrators, was marked in the field (on trees) or forest maps by foresters (information obtained from Prof. Krystyna Czesława Paluszyńska-Daszkiewicz).

\subsection{Infodemic After the II World War}

Infringing international agreements and laws is a serious problem for a state which is guilty of such acts. Not obeying the war laws especially in reference to soldiers who were taken captive was a condemnable fact. It was not in the interest of the USSR to reveal the truth. Furthermore, it would have opened ground for compensation claims. After the Nuremberg trials in the course of which Nazi atrocities had been revealed, the worldwide public opinion and authorities started talking about the crimes of genocide. Since that time, genocide has been considered a crime and has been regulated by various international and national laws. The meaning of the term is constantly modelled as new genocide modes are detected. Together with the establishment of the concept of the crime, various methods of its covering have come to existence. One of them is spreading misinformation which if applied in special circumstances may be called infodemic.

Infodemic is a word coined in twenty-first century as a blend of the terms information and epidemic. It is defined as the spread of information, including fake news, that is detrimental and hinders the procedure of solving problems by causing misinformation, flooding media with fake news, etc.

When analyzing the source materials, frequently published by historians in collections of archival documents, one cannot escape the conclusion that the phenomenon so recently named in a precise way has been exploited for ages. The infodemic may also be found in sources addressing Katyń genocides and labour camps in the USSR. 
The so-called Katyń genocides for decades were masked and presented in compliance with the Soviet and communist propaganda in Poland. The fact that the representatives of Polish elites were exterminated without any trial, frequently by shot in the back of the head was very inconvenient in the times of the Cold war and new political alliances. How was it possible? Forensic medicine was not as advanced as now. But there were reports of the Red Cross doctors as well determining the time of death to be 1940. The contact with the Polish officers in question definitively ended in 1940. Furthermore, the German troops entered the territories were the Katyn genocide took place in August 1941. The Soviet government wanted to make the Germans culprits of the crime by proving that the killings took place after 31 July 1941. Let us present and analyse briefly some documents showing facts and infodemic spread by various interested parties to provide some insight into the language usage for justifying and giving extermination orders, spreading propaganda, hiding facts and revealing the truth $[9,10,21,22]$.

In the note dated to March 5, 1940, drafted in Moscow (Note from Lavrentija Beria to Josef Stalin regarding the plan to murder Polish prisoners of war (No. 794-B strictly secret from 5 March [19] 40 KC WKP (b)) we read:

[...] At present, a great number of former Polish Army officers, former employees of the Polish police and intelligence bodies, members of Polish nationalist [revolution] parties, members of disclosed [revolution] parties, members of insurgent organizations, refugees and others are being held in the USSR NKVD camps for prisoners of war and in the prisons of the western regions of Ukraine and Belarus. They are all fierce enemies of the Soviet power, full of hatred for the Soviet system. (...) Considering that they are all hardened, non-propelling enemies of the Soviet power, the NKVD of the USSR considers it necessary: (I) To order the NKVD of the USSR: 1) to deal with 14,700 people - the prisoners of war, former Polish officers, officials, landowners, policemen, intelligence agents, gendarmes, settlers and prison service who are in camps, 2) as well as to deal with 11,000 persons - those arrested and in prisons in the western regions of Ukraine and Belarus, members of various organizations [revolutionary] organizations, former landowners, factory owners, former Polish officers, officials and fugitives - they shall be examined in a special mode, applying the highest penalty to them - shooting dead. (II). Cases shall be resolved without summoning those arrested, without bringing charges, without giving decisions to terminate the investigation and without issuing indictments. [21: 469-470, 475].

The next document worth quoting here is the excerpt from the minutes of 13 meetings of the Political Bureau of the Central Committee of the Communist Party of Ukraine (Decision on the murder of Polish prisoners of war and prisoners Top secret (the resolution of March 5 1940. No. 144. Case of the NKVD of the USSR I. Order for the NKVD of the USSR 1940 March 5, Moscow)) which in fact quotes the previously cited text:

I. Order the NKVD of the USSR: 1) to deal with the prisoners of war in the amount of 14,700 people: former Polish officers, officials, landowners, police- 
men, intelligence agents, gendarmes, settlers and prison service who are in camps, 2) as well as to deal with those arrested and in prisons in the western regions of Ukraine and Belarus in the amount of 11,000 persons: members of various organizations [evolutionary] organizations, former landowners, factory owners, former Polish officers, officials and fugitives - they shall be examined in a special mode, applying the highest penalty to them - shooting dead. II. Cases shall be resolved without summoning those arrested, without bringing charges, without giving decisions to terminate the investigation and without issuing indictments [21: 476].

Two days later a new document is created. It is the Directive of the People's Commissar of Internal Affairs of the USSR Lavrenty Beria for People's Commissars of Internal Affairs of the USSR, Ivan Serov and BSRR Lavrenty Canava (also spelled Tsanava) regarding the deportation to the Kazakh SSR of family members of prisoners of war and prisoners of the People's Commissar of the Interior of the USSR Commissioner of State Security of 7 March 1940:

3. Comrade Serov the People's Commissar for Internal Affairs of the BSSR St. Major of State Security Comrade Canava NKVD USSR recommend that the following persons be deported to the regions of the Kazakh SSR until April 15 for a period of 10 years: all family members of the former Polish army officers, police officers, prison guards, gendarmes, intelligence agents, former landowners, factory owners and high state officials of the former Polish state apparatus, detained in prisoner-of-war camps and prisons western regions of Ukraine and Belarus. In order to implement this decision, I order: 1. Immediately start and finish by March 30 this year the preparation of the exact records of family members of all the above categories of prisoners of war and arrested according to the attached precise template. Note: Family members are considered to be the wife, children, as well as parents, brothers and sisters if they live with the family of a detained person or prisoner of war. [...] 5. When developing the plans for the operation, the following directives should be followed: [...] c) The operation is carried out in all western regions of Ukraine and Belarus during one day and begins at dawn. There will be an additional notification about the day of the operation. [...] e) Immovable property as well as commercial and industrial enterprises of deported families shall be confiscated. Deported families have the right to take personal items of a maximum weight of $100 \mathrm{~kg}$ per each family member, including children, to the place of deportation. [...] People's Commissar for Internal Affairs of the USSR Commissioner for State Security [...] Lawrientij Beria. [10: 43-46].

On 13 April 1943 at 9.15 New York time zone the German radio broadcast the first information about the mass graves in the region of Katyn.

Berlin: They report from Smolensk that the local population showed the German authorities the place of secret mass executions carried out by the Bolsheviks and where the GPU (State Political Directorate) murdered 10,000 Polish officers. German authorities went to the town of Kosogory, which is a Soviet 
spa, located $16 \mathrm{~km}$ west of Smolensk, where they made a terrible discovery. They found a pit $28 \mathrm{~m}$ long and $16 \mathrm{~m}$ wide, in which there were 3,000 Polish officers' corpses arranged in 12 layers. They were in full military uniforms, partly tied and all had wounds from revolver shots in the back of their heads. Identifying the corpses will not be difficult because they are well mummified because of the properties of the soil and because the Bolsheviks have left their papers with their bodies. It has already been established that among the murdered there is general Smorawiński from Lublin. The officers were initially in Kozielsk near the city of Oryol, from where they were brought in cattle wagons to Smolensk in February and March 1940, and from there transported by trucks to Kosogor, where the Bolsheviks murdered them all. [...] [19: 85].

Moscow responds to the broadcast instantaneously using the same mode of mass communication, that is to say the radio:

15 April 1943, at 7:15, Moscow: Over the past two or three days, the slanderers of Goebbels spread vile fabrications, maintaining that the Soviet authorities massively executed Polish officers in the spring of 1940 near Smolensk. When informing about this monstrosity, the German-fascist rascals of Goebbels do not hesitate to spread the most shameless and wicked lies, trying to cover crimes that - as it has now become apparent - were committed by them. German-fascist reports in this case leave no doubt as to the tragic fate of former Polish prisoners of war who were employed in construction works in 1941 in the area west of Smolensk and who, along with many Soviet subjects residing in the area of Smolensk, fell into the hands of German-fascist torturers in the summer of 1941, after the withdrawal of Soviet troops from the Smolensk region. In their inept fabrications about the numerous graves that the Germans allegedly discovered near Smolensk, Nazi liars mention the village of Gnyozdovo. But as befits fraudsters, they are silent about the fact that the archeological excavations of the historic cemetery were carried out near the village of Gnyozdovo. [19: 86].

On 25 April 1943 Vyacheslav Molotov, the Minister of Foreign Affairs of the USSR, sends a letter to Tadeusz Romer - the Extraordinary Plenipotentiary Ambassador of the Republic of in Moscow. The letter reads as follows:

The Soviet Government considers the recent behaviour of the Polish Government towards the USSR completely abnormal and violating all regulations and customs in relations between the two allied countries. A slanderous campaign, hostile to the Soviet Union, developed by German fascists in connection with the murder of Polish officers, which they themselves had committed in the vicinity of Smolensk in the area occupied by the German army, has immediately been followed by the Polish Government and carried out by the Polish press official with all possible means. Far from doubting the fascist slander against the USSR, the Polish Government has not even considered it necessary to ask the Soviet Government a question or to request a clarification in this matter. Having committed a monstrous crime against Polish officers, 
the Nazi authorities have been currently staging the farce of investigation [...]. In this case, both governments - Polish and Nazi - have invited the International Red Cross. It is clear that this kind of 'investigation', conducted behind the back of the Soviet Government, cannot inspire confidence in people with even the slightest sense of honesty. [...] While the peoples of the Soviet Union, bleeding profusely in heavy fighting against Nazi Germany, make every effort to defeat a common enemy [...] the Polish government strikes a treacherous blow to the Soviet Union in order to please Hitler's tyranny. [...] In connection with all this, the Soviet Government decided to sever relations with the Polish Government. [26: 505-506].

The Soviet version of history actually was followed after the World War II by the Polish communist authorities. We may find some examples in history coursebooks and encyclopedias. Let us quote just a few examples:

At that time, the Western imperialists used the Polish reaction circles to unleash a hideous anti-Soviet campaign. At the beginning of 1943, the London 'government' issued a provocative enunciation regarding the lands of Ukraine and Western Belarus, in which it demanded the recognition of the right to oppress these lands by the bourgeoisie and Polish landowners. The further stage of this campaign was the support of the wicked Katyn provocation. In the spring of 1943, the émigré 'government' directly became a tube of Nazi propaganda, launching a vile slander campaign against the Soviet Union internationally to break up the war bloc of England, America and the USSR in accordance with the wishes of the Nazis. Such a great political diversion has been unleashed by Goebbels' propaganda, appealing to imperialist, anti-Soviet groups in the West, eagerly picked up by the Polish reaction, the hideous antiSoviet provocation - using the notorious case of Nazi fascist crime on Polish officers in Katyń. The London 'government' has immediately eagerly picked it up and actively supported Goebbels' provocation, thus revealing its proHitler face. This overt support for the provocative, anti-Soviet actions of the Nazi government caused the Soviet government to break diplomatic relations with the Polish government on April 25, 1943. The Polish émigré government in London has revealed itself as the anti-Soviet leader of the most aggressive Anglo-American reaction circles [14, 33: 425].

About the same time the new document is drafted in Moscow and delivered to its addressee. It is a top secret note of the head of the USSR KGB Alexander Nikolayevich Shelepin for the Prime Minister of the USSR Nikita Khrushchev with the proposal to destroy the record files of Polish prisoners of war murdered in 1940. The note is dated to 9 March 1959.

In 1940, the State Security Committee of the USSR Council of Ministers census files and other materials regarding prisoners of war and interned officers, gendarmes, policemen, etc. of persons from former bourgeois Poland are kept. In total, 21,857 people were shot on the basis of the decision issued by the Special Three of the NKVD of the USSR [...]. Since the operation was carried 
out, i.e. since 1940, no information on these matters has been issued to anyone and all 21857 files are kept in a sealed room. All these files represent neither operational interest nor historical value for the Soviet authorities. It is doubtful that they can be of interest to our Polish friends. [...] Therefore, it seems purposeful to destroy all registration files regarding persons shot in 1940 as part of the above-mentioned operation. The draft resolution of the CPSU Central Committee is attached. The Chairman of the State Security Committee of the USSR Council of Ministers. Alexander Shelepin's Project. Top secret Resolution of the Presidium of the CPSU Central Committee of 1959. Allow the State Security Committee of the USSR Council of Ministers to liquidate all files of the operation carried out in accordance with the Resolution of the CPSU Central Committee of March 5, 1940, except for the minutes of the meetings of the Special Three of the NKVD of the USSR. [11: 416-420].

The entry "Katyń" in the Encyclopedia [32] published in 1959 by the National Scientific Publishing House (Państwowe Wydawnictwo Naukowe-PWN) informs that:

Katyn - a place in the Smolensk region of the RSFSR (The Russian Soviet Federative Socialist Republic), the place of the mass graves of several thousand Polish officers interned in the USSR since 1939, and murdered by the Nazis after taking over these areas. (Encyklopedia PWN, 1959: 407.)

On 15 April 1971 the secret Instructions for Soviet ambassadors in London and Warsaw in reference to point 35 of Protocol No. 1 is issued in Moscow.

You will go to the Ministry of Foreign Affairs of England and declare as follows: "According to the information held by the Embassy, the BBC television is going to show a film prepared by it, hostile to the Soviet Union, about the so-called Katyń case. This has been linked to the publication of a slanderous book about the Katyń tragedy in England. It is well known to the English side that the Nazis' guilt for this crime has been indisputably proven by an authoritative special commission which investigated the crime on the spot, immediately after the expulsion of German occupiers from the Smolensk region. In the years 1945- 1946 the International War Tribunal in Nuremberg found the main German war criminals guilty of pursuing a policy of destroying the Polish nation, including shooting dead Polish prisoners of war in the Katyń Forest." Telegraph when the order is executed. (Only for Warsaw: you will inform the Ministry of Foreign Affairs of the People's Republic of Poland about the guidelines provided to the Soviet ambassador in London.) The original State Archivist of the Russian Federation (-) signature R.G. Pichoya [30: 51].

The secret Circular for members of the CPSU Central Committee Political Bureau regarding a speech to the UK government in connection with the construction of the Monument to the Victims of Katyń in London is issued on 7 September 1972 in Moscow.

Reaction circles in England, for anti-Soviet purposes, are again attempting to spread the so-called Katyń case. To this end, a campaign is being 
used to raise funds for the construction of the 'Monument to the Victims of Katyń' in London. The Ministry of Foreign Affairs of the USSR would consider it expedient to draw the British government's attention to this hostile Soviet campaign in England by presenting the oral demarché to the English ambassador in Moscow. [...]. W. Kuzniecov [30: 59].

We may also find Polish censorship instructions referring to Katyń genocides. One of the examples is the Instructions of the Main Office for Control of Press, Publications and Performances of January 1975 [31] in which we read:

... (2) In scientific, memoir and biographical studies one can accept phrases such as "shot by the Nazis in Katyń", "died in Katyń", "lost life in Katyń". When the date of death is given in the case of the use of words such as "died in Katyń", it can only be determined after July 1941. (3) The term "prisoners of war" should be eliminated in relation to Polish soldiers and officers interned by the Red Army in September 1939 r. The correct term is "interned". [...] (4) Obituaries, death notices, announcements about religious services in the intention of the victims of Katyn and information about other forms of commemoration may be released only with the consent of the management of the Main Office for Control of Press, Publications and Performances [...]. [31: 63].

The anti-communist movement in eastern Europe at the end of $80 \mathrm{~s}$ of the twentieth century gives rise to new opportunities of counteracting propaganda and infodemic. On 22 March 1989 the secret Note of the USSR Minister of Foreign Affairs Eduard Shevardnadze, Valentin Falin and the chairman of the USSR KGB Vladimir Kryuczkov regarding the policy towards the Katyń case No. 17-204 No. KC 06772 (Secret Central Committee of the CPSU) is drafted. It states as follows:

On the Katyń issue: As the critical dates of 1939 anniversary approach, the discussion around the so-called white spots in relations with the USSR (Russia) is becoming increasingly sharp in Poland. In recent weeks, the main attention has been focused on Katyń. Among the publications, whose authors are activists known for their opposition views, as well as scholars and journalists close to the Polish leadership, it is openly argued that the Soviet Union was to blame for the annihilation of Polish officers, and that the shooting took place in the spring of 1940. [...] We probably will not be able to avoid explaining to the leadership of the Polish People's Republic and Polish society the tragic issues of the past. Time is not our ally in this case. Perhaps it would be expedient to say how it was in reality and who exactly is to blame for what happened and to close the case with it. In the end, the costs of doing so would be lower compared to the losses caused by the current indolence. A draft decision of the CPSU Central Committee attached. Eduard Shevardnadze, Valentin Falin, Ladimir Krishkov, March 2, 1989 No. 17-204 No. KC 06772 [22].

Finally, the truth is accepted but the blame is not. On 2 August 1993, the Judgment of the Commission of Russian experts (in the field of law, history, medicine and the army) of the Supreme Military Prosecutor's Office of the Russian Federation examining the materials of criminal case No. 159 regarding the shooting of Polish 
prisoners of war is given in Moscow. Some conclusions of the judgment are cited below:

[...] Conclusions 1. The materials gathered in the files of the investigation contain convincing evidence of the fact of a crime - a mass murder committed by the NKVD authorities in the spring of 1940 [on] 14,522 Polish prisoners of war from the NKVD camps in Kozel, Starobelsk and Ostashkov, who were sent in batches from April 3 to May 19, 1940 to the place of execution and shot dead (shots in the back of the head) partly in the Katyn Forest, in the prisons of the NKVD boards of Smolensk, Kharkiv and Kalinsk oblast [district], after which they were buried in mass graves in the Katyn Forest, the village of Mednoye Kalinska oblast and in the forest areas of Kharkov park. [...] It was also proven that, as part of the same decision, 7305 Poles, including about 1,000 officers, were shot in NKVD prisons of Western Belarus and Western Ukraine. [...] In September-December 1939, the category of prisoners of war who were placed in prisoner-of-war camps included both soldiers taken prisoner in the course of combat operations of the Red Army, as well as those identified during subsequent registration. In the three NKVD special camps - Kozelsk, Starobelsk and Ostashkov - over 15,000 persons were concentrated out of whom 56.2 percent were officers (officers in active service constituted $44.9 \%$, reserve officers $-55 \%$, the rest - retired officers, including invalids of the 1920 war). The remaining were primarily police officers and officials of the central and local levels of state administration, judges, prosecutors, customs officers, etc. [...] After the "liberation march" in Western Belarus and Western Ukraine, the beginning of strenuous "socialist transformations" and introducing the transformation of the social and political structures, Stalinist leadership through the NKVD organs undertook a massive "screening" of "class and nationally foreign elements". [...] 6. [...] It was a war crime for which the following persons should bear responsibility: Stalin and other members of the Stalinist leadership - Molotov, Beria and members of the Political Bureau of the Central Committee of the Communist Party who adopted a resolution on the mass extermination of innocent people: Mierklov, Kobulov, Basztakov, Soprunienko. Also officers of the NKVD of the USSR, NKVD of the Ukrainian and Byelorussian SSR, who at various levels took part in the preparation and implementation of this criminal decision: Blochin, Milsztejn, Sininububov and heads of NKVD boards of Smolensk, Kharkiv and Kalinsk oblasts, their first deputies, commanders and officers of individual prisons, drivers and guards who carried out criminal orders and other persons who participated in the shooting of Polish prisoners of war and Poles from prisons and detention centers in Western Belarus and Western Ukraine. According to the Convention on the Non-Applicability of Statutory Limitations to War Crimes and Crimes Against Humanity (regulating the non-prescription of crimes against peace, war crimes and genocide crimes), the abovementioned persons were guilty of the murder of 14,522 Polish prisoners of war from Kozelsk, Starobelsk and Ostashkov NKVD camp of the USSR and 7,305 Poles kept in prisons and camps of Western Belarus and Western Ukraine, they all shall incur legal 
liability in accordance with internal legislation for unlawful abuse of power - Art. 171 of the Criminal Code of the RSFSR from 1929 [which] led to calculated murder - art. 102 of the Criminal Code of the RSFSR - on a particularly large scale, which should be treated as genocide. [...] Experts: Topornin, Jakovlev, Yazhborovskaya, Parsadanova, Zoria, Bielayev [23: 57ff].

But the final outcome may be surprising. Despite the fact that the worldwide public opinion is informed about the facts and the truth is finally admitted the process of spreading infodemic is not stopped. The Russian Chief Military Prosecutor Alexander Savienkov during a special press conference on 11 March 2005 announced the discontinuation of the investigation into the Katyń massacre, stating that no fact of the crime of genocide could be confirmed and the guilty ones are dead so no one might be punished. On 4 April 2005 the International Association "Memorial" has issued the Statement of the Board regarding the investigation into the Katyń massacre in Russia:

We believe that the discontinuation of the investigation is unacceptable. First of all - even if it was not a crime of genocide, it should be announced how these executions are qualified - as a war crime, as a crime against humanity or as a premeditated murder with aggravating circumstances? Closing the investigation without legal qualification seems to be an attempt to refuse any liability for the crime. Secondly, the identity of a significant portion of the victims (almost 4,000) has not been established yet, namely prisoners shot dead in Belarus. The Supreme Military Prosecutor's Office refers to the fact that crimes that were committed outside the current Russia should be prosecuted by the justice authorities of the respective countries. In this case, the argument is not convincing, because the decision to shoot Polish citizens dead was made in Moscow, there the entire operation was directed, there all the reports including the ones about its course flowed [...]. Thirdly, the statement made by the Chief Military Prosecutor of Russia that "the death of only 1803 prisoners is confirmed" should be explained as it is well known that over 14.5 thousand were killed. Finally, the investigation into the Katyn massacre cannot be closed without establishing and disclosing the names of all those who took part in it - both initiators (who are already known) and executors at all levels. We understand that criminals who are already dead cannot be tried. However, their names should be announced. This happened and has been happening in all civilized countries, usually without establishing special tribunals. This is also required by Russian legislation, in particular the Act on the Rehabilitation of Victims of Political Repression (part II, art. 18). The decision of the Russian Supreme Military Prosecutor's Office to classify most of the investigation materials (including the decision to discontinue the criminal case) is also unacceptable. This decision is unlawful because, according to the Act on State Secrets: "Information about the facts of violation of human and civil rights and freedoms is not subject to state secret and cannot be classified" (Article 7). Signed by the Board of the International Association "Memorial" April 4, 2005 [13]. 
As we can conclude from the analysis of source materials quoted above the infodemic discourse is characterized by very strongly emotionally loaded adjectives, adverbs and nouns. The language is over-persuasive. It expresses strong emotions, outrage and aims at degrading the adversaries as untrustworthy and slanderous bullies. The propaganda and persuasion aims are achieved by using phrases such as "fierce enemies", "full of hatred", "hardened, non-propelling enemies". Those attributes of the social profile of prisoners is considered a sufficient justification for a postulate to have them shot dead without any trial. The discourse aimed at hiding the truth is also similar. We find such emotionally loaded expressions there as: "shameless and wicked lies", "fascist torturers", "abnormal and violating all regulations and customs [behaviour]", "a monstrous crime", "to stage the farce of investigation", "investigation conducted behind the back of the Soviet Government", "inspire confidence in people with even the slightests sense of honesty", "bleeding profusely in heavy fighting", "German-fascist rascals", "a treacherous blow", "a hideous anti-Soviet campaign", the wicked Katyń provocation”, a vile slander campaign", "hostile to the Soviet Union", etc.

Both types of messages that aim at revealing and aiming the truth contain expressions such as: "tragic fate", "monstrosity", "massacre".

The discourse of texts based on facts (the objective truth) drafted by all sides reporting the genocide operations (e.g. documents quoted above such as: the NKVD order to execute the prisoners, the note of 9 March 1959 to destroy the files, the German radio broadcast of 13 April 1943, the Judgment of 2 August 1993, the Letter of the "Memorial" Association of 4 April 2005) contain numerical data such as the number of prisoners, the number of executed, the size of the graves, the number of layers in which bodies were stuck, the dates. What is more, they contain the proper names of places where discussed events took place. Additionally, documents which touch upon legal aspects of crimes refer to specific legal provisions, soft-law and orders issued by authorities.

\section{Conclusions}

The lawyers and historians in Poland are of the opinion that:

it should be finally recalled that the Soviet Union was bound at the time of the Katyń genocides by international conventions on the protection of prisoners of war, and despite these conventions, at the beginning of the aggression against Poland, the USSR was handing over captured prisoners of war to the security authorities (NKVD), rather than the dedicated agencies of the Red Army; the Katyń genocides - despite a relatively small number of victims - constitute a crime of genocide, since it aimed at eliminating a group of citizens of the Polish state with significant intellectual and professional potential. Thus, it cannot be barred, except that any limitation period may be counted from 13 December 1990, i.e. from the date of the official disclosure of the perpetrators. [15: 59].

Taking into account the contemporary laws on genocide one must support that point of view. In the light of The United Nations Declaration on the Rights of Indigenous 
Peoples (UNDRIP) which was adopted by the General Assembly on Thursday, 13 September 2007, that is a benchmark for delineating the modern meaning of genocide, we may state that foresters were the indigenous people living at the Polish soil and their rights specified under article 7 were violated. ${ }^{2}$

They were forced to live their homes having just several minutes to pack most important things, leaving behind their belongings, family memoires and the land they loved. ${ }^{3}$ In article 10 of the Declaration we read:

\section{Article 10}

Indigenous peoples shall not be forcibly removed from their lands or territories. No relocation shall take place without the free, prior and informed consent of the indigenous peoples concerned and after agreement on just and fair compensation and, where possible, with the option of return.

The relocation of foresters was forced on pain of death of whole families and frequently led to deaths out of exhaustion, malnutrition, torture and other forms of treatment violating human right and depriving them of everything that we value including traditions, customs and broadly understood culture. ${ }^{4}$

Kostrzewski [15: 54-55] stresses that

the Katyń massacre escapes any criteria of the legal systems of civilized states. And that's why it is described as the largest crime of World War II. Not because of the number of victims, but because of its legal aspect, primar-

\section{Article 7}

1. Indigenous individuals have the rights to life, physical and mental integrity, liberty and security of person.

2. Indigenous peoples have the collective right to live in freedom, peace and security as distinct peoples and shall not be subjected to any act of genocide or any other act of violence, including forcibly removing children of the group to another group.

3 Article 8

1. Indigenous peoples and individuals have the right not to be subjected to forced assimilation or destruction of their culture.

2. States shall provide effective mechanisms for prevention of, and redress for:

(a) Any action which has the aim or effect of depriving them of their integrity as distinct peoples, or of their cultural values or ethnic identities;

(b) Any action which has the aim or effect of dispossessing them of their lands, territories or resources;

(c) Any form of forced population transfer which has the aim or effect of violating or undermining any of their rights;

(d) Any form of forced assimilation or integration;

(e) Any form of propaganda designed to promote or incite racial or ethnic discrimination directed against them.

4 Article 9

Indigenous peoples and individuals have the right to belong to an indigenous community or nation, in accordance with the traditions and customs of the community or nation concerned. No discrimination of any kind may arise from the exercise of such a right.

Article 11

1. Indigenous peoples have the right to practise and revitalize their cultural traditions and customs. This includes the right to maintain, protect and develop the past, present and future manifestations of their cultures, such as archaeological and historical sites, artefacts, designs, ceremonies, technologies and visual and performing arts and literature. 
ily its international legal aspect. It was carried out on the citizens of another state, additionally protected by international conventions, as prisoners of war, by a state that did not conduct any warfare at that time, and therefore in peace, when prisoners of war should be released from captivity, because the reason for their further stopping. It should be emphasized that some of these prisoners of war were protected by additional international conventions - doctors and clergy, who in principle should be released immediately after confirming their status, and during the stay in the camp should be provided with adequate conditions to perform their professional duties. The criminal activity of the Soviet state against Polish prisoners of war - officers - was therefore not limited to the actual deprivation of their lives. the framework applied collective responsibility to the families of victims of crime. These families, when they could be reached, were deported from their homes, deprived of their belongings.

He continues pointing out the infodemic aspect of the genocide:

The culmination of these criminal activities was finally the silence surrounding it combined with an attempt to place the blame for it on another state Germany. This silence surrounding the crime, imposed on the whole world in many ways, was its continuation, because it became its blind adherence. That is why talking about the legal aspect of the Katyń massacre today is so difficult and complicated.

and the lack of willingness to accept the criminal liability for the crimes committed by the Soviet Union:

On April 13, 1990 at 14.30 TASS announced a statement in which it was written: 'The entire archival materials disclosed allow the conclusion about direct responsibility for the crimes of Beria, Mierkulov and their helpers in the Katyn Forest. The Soviet side, deeply regretting the Katyn tragedy, declares that it is one of the grave crimes of Stalinism' (...) In the next part of the statement it is acknowledged that the Soviet Union bears moral and political responsibility for this crime, but the legal liability (allowing the guilty party to be brought to justice and enabling to demand financial compensation on behalf of the families (heirs) of the victims) has been omitted.

The exact numbers of foresters who lost their lives in Katyń genocides and forced labour camps is not known and may never be known. The data from archives are not complete and there is not much chance of revealing evidence on families that were deported and their relatives no longer live. The assessments based on the available data are nevertheless pretty credible which enables us to state that foresters were persecuted because of their profession - which turned out to be lethal. The elements of education and insight knowledge of foresters contributed for sure to their extermination and persecution. Those among others included:

1. They could read, write and do calculations which taking into account the illiteracy rate at that time in Europe made them equipped in important skills and potentially intellectually/politically dangerous. At least $62.57 \%$ of the so-called Katyń 
genocides had higher education or were in the process of acquiring one when the second world war interrupted.

2. Their education frequently acquired at agricultural and forest universities or vocational secondary schools made them the elite group in the country.

3. The knowledge of the topography of forests that served at that time as the partisan/insurgent shelter. Foresters served as guides to partisan units. They also documented and remembered mass graves in which bodies of murdered people were buried.

4. Their knowledge and practical skills in the field of logging and timber production was highly desired and could be taken advantage of by the administration of gulags that provided the national economy of the USSR with $25.3 \%$ of its timber.

5. As people spending much time in the forest, close to nature they were the group allowed to have weapon permits and were considered skillful shooters. Their ability to shoot precisely frequently during the first and second world war made them mobilized and trained as snipers.

To sum up, it should be stressed that as the historical records prove some groups are more frequently subjected to genocide than others. The semiotic analysis of the profile of victims of various genocides also reveals that the elite of society is the most endangered group and usually first to be targeted. But the semiotic analysis of source documents reveals that the so-called historical truth is a truth and its content depends on the intentions and interests of message senders and recipients. Infodemic is therefore a dangerous phenomenon which has been exploited to manipulate public opinion and distort the facts for ages. Thus, it is a tool of propaganda, misinformation and psychology of crowds leading to highly undesirable consequences.

Acknowledgements Authors would like to thank prof. dr. hab. Władysław Chałupka, prof. dr. hab. Andrzej Grzywacz and dr. Tomasz Skowronek for sharing some documents, legal acts and publications.

Authors Contributions Introduction by AM and DJG, Research methods and materials by AM, Definition of genocide by AM, A lethal profession by AM, How many educated foresters were in the interwar period in Poland? by DJG, How many foresters worked in the territory occupied by Soviets in 1939 ? by DJG, Semiotic analysis of factors contributing to the genocide of foresters by AM, pictures provided by DJG, Genocide in Gulags by AM and DJG, Other reasons for persecution of foresters by DJG, Infodemic after the II World War by AM, Conclusions and Bibliography by DJG and by AM, Translation of quotations into English by AM, proofreading and editing by AM.

Open Access This article is licensed under a Creative Commons Attribution 4.0 International License, which permits use, sharing, adaptation, distribution and reproduction in any medium or format, as long as you give appropriate credit to the original author(s) and the source, provide a link to the Creative Commons licence, and indicate if changes were made. The images or other third party material in this article are included in the article's Creative Commons licence, unless indicated otherwise in a credit line to the material. If material is not included in the article's Creative Commons licence and your intended use is not permitted by statutory regulation or exceeds the permitted use, you will need to obtain permission directly from the copyright holder. To view a copy of this licence, visit http://creativecommons.org/licen ses/by/4.0/. 


\section{References}

1. Bacon, Edwin. 1996. The Gulag at War: Stalin's Forced Labour System in the Light of the Archives. London: Palgrave Macmillan.

2. Broda, Józef (ed.). 2004. Wśród śniegów i bagien tajgi. Relacje leśników deportowanych w 1940 roku z ziem wschodnich II Rzeczpospolitej w głab Zwiazku Radzieckiego. Poznań: Wydawnictwo Akademii Rolniczej im. Augusta Cieszkowskiego w Poznaniu.

3. Broda, Józef. 2007. Dzieje najnowsze leśnictwa w Polsce 1918-2006, vol. 1. Warszawa: Polskie Towarzystwo Leśne.

4. Budniak, Florian. 1994. Od PWL do Batalionu Las. Gołuchów: Ośrodek Kultury Leśnej.

5. Bul, Konrad. 2006. Leśnicy w szeregach polskiego podziemia. In $Z$ dziejów Lasów Państwowych $i$ leśnictwa polskiego 1924-2004, vol. 2, ed. Andrzej Szujecki, 147-182. Warszawa: Centrum Informacyjne Lasów Państwowych.

6. Chałupka, Władysław, and Jerzy Modrzyński. 2012. Polscy studenci w Królewskiej Saskiej Akademii Leśnej w Tharandcie w latach 1816-1919. Studia i Materiaty Ośrodka Kultury Leśnej 11: 17-50.

7. Chrzanowski, Tadeusz (ed.). 2014. Dwunastu z listy katyńskiej. Leśnicy i drzewiarze z Pomorza i Kujaw, ofiary Zbrodni Katyńskiej. Toruń: Regionalna Dyrekcja Lasów Państwowych, Polskie Towarzystwo Leśne. Oddział w Toruniu.

8. Chrzanowski, Tadeusz. 2015. Udział leśników w walkach i działalności „Gryfa Pomorskiego”. In Znaczenie lasów w obronności kraju, ed. Andrzej Grzywacz. Warszawa: Polskie Towarzystwo Leśne: $29-47$.

9. Gieysztor, Aleksander, and Rudolf Pichoja (eds.). 1995. Katyń. Dokumenty zbrodni, vol. 1, Jeńcy niewypowiedzianej wojny VIII 1939 - III 1940. Warszawa: Naczelna Dyrekcja Archiwów Państwowych i Wydawnictwo Trio.

10. Gieysztor, Aleksander, and W. Kozłow (eds.). 1998. Katyń. Dokumenty zbrodni, vol. 2, Zagłada. Warszawa: Naczelna Dyrekcja Archiwów Państwowych i Wydawnictwo Trio.

11. Grzywacz, Andrzej. 2019. Adam Loret - pierwszy naczelny dyrektor Lasów Państwowych. In W stużbie ludziom i przyrodzie ed. Dariusz J. Gwiazdowicz. Sandomierz: Wydawnictwo Diecezjalne i Drukarnia w Sandomierzu: 129-144.

12. Ivanova, Galina Mikhailovna. 2000. Labour Camp Socialism: The Gulag in the Soviet Totalitarian System, 69-126. New York: Sharpe.

13. „Karta” Biuletyn Historycznej Agencji Informacyjnej. 2005, no. 44:145-146.

14. Kormanowa, Żanna (ed.). 1953. Historia Polski 1864-1945. Materiaty do nauczania w klasie XI, zatwierdzone do użytku szkolnego na rok szkolny 1952/53 i 1953/54. Warszawa: Państwowe Zakłady Wydawnictw Szkolnych.

15. Kostrzewski, Andrzej. 1997. Prawne aspekty zbrodni katyńskiej. Zeszyty Katyńskie no. 8, Ku cmentarzom polskim w Katyńiu, Mednoye, Charkowie, eds. Marek Tarczyński and Janina SnitkoRzeszut. Warszawa: Niezależny Komitet Historyczny Badania Zbrodni Katyńskiej. Polska Fundacja Katyńska: 52-61.

16. Kryczyński, Walenty 1977. Wyższe szkolnictwo leśne. In Nauki Leśne w Polsce 1920-1970, ed. Antoni Żabko-Potopowicz. Wrocław-Warszawa-Kraków-Gdańsk: Wydawnictwo Polskiej Akademii Nauk: 19-29.

17. Kusiak, Władysław 2019. Wyróżniający się patriotyczną postawą poznańscy profesorowie leśnictwa. In W stużbie ludziom i przyrodzie, ed. Dariusz J. Gwiazdowicz. Sandomierz: Wydawnictwo Diecezjalne i Drukarnia w Sandomierzu: 215-242.

18. Lemkin, Raphael. 1944. Axis Rule in Occupied Europe: Laws of Occupation, Analysis of Government, Proposals for Redress. Washington, DC: Carnegie Endowment for International Peace Division of International Law. New York: Columbia University Press: 79-95.

19. Mackiewicz, Józef and Zdzisław Stahl, 1982. Zbrodnia katyńska w świetle dokumentów (z przedmową gen. Władysława Andersa), London: no printing house data provided.

20. Martyrologia Leśników. Katyń, Sybir, Kresy https://www.lasy.gov.pl/pl/wideo/telewizja-lasow-panst wowych/wideo/martyrologia-lesnikow-Katyń-sybir-kresy. Accessed 5 April 2020.

21. Materski, Wojciech (ed.). 2001. Katyń. Dokumenty zbrodni, vol. 3, Losy ocalatych. Lipiec 1940 marzec 1943. Warszawa: Naczelna Dyrekcja Archiwów Państwowych i Wydawnictwo Trio. 
22. Materski, Wojciech, Ewa Rosowska, Boleslaw Woszczynski, Natalia S. Lebiediewa and Neli A. Pietrosowa (eds.). 2006. Katyń. Dokumenty zbrodni, vol. 4, Echa Katyńia. Warszawa: Naczelna Dyrekcja Archiwów Państwowych i Wydawnictwo Trio.

23. Mitzner, Piotr, Ileana Porycka, and Alicja Wancerz-Gluzared. 1994. Rosja a Katyń. Warszawa: „Karta” Biuletyn Historycznej Agencji Informacyjnej.

24. Molenda, Tadeusz 1977. Polityka państwa w rozwoju nauk leśnych. In Nauki Leśne w Polsce 19201970, ed. Antoni Żabko-Potopowicz. Wrocław-Warszawa-Kraków-Gdańsk: Wydawnictwo Polskiej Akademii Nauk: 19-29.

25. Ochotin, Nikita, and Arsienij Roginski. 1998. Łagry. Przewodnik Encyklopedyczny. Warszawa: Ośrodek Karta.

26. Pełczyński, Tadeusz, Jan Tokarski, et al. (eds.). 1990. Armia Krajowa w dokumentach 1939-1945, t. 2: Czerwiec 1941 - kwiecień 1943. Wrocław: Zakład Narodowy im. Ossolińskich.

27. Rosefielde, Steven. 1981. An Assessment of the Sources and Uses of Gulag Forced Labour 1929-56. Soviet Studies 33(1): 51-87. Retrieved from www.jstor.org/stable/151474. Accessed on 21 January 2020.

28. Skowronek, Tomasz. 2014. Leśnicy w grobach Katyńia, Charkowa, Mednoye, Bykowni, Kuropat. In: Dwunastu z listy katyńskiej. Leśnicy i drzewiarze z Pomorza i Kujaw, ofiary Zbrodni Katyńskiej, ed. Tadeusz Chrzanowski. Toruń: Regionalna Dyrekcja Lasów Państwowych, Polskie Towarzystwo Leśne. Oddział w Toruniu: 111-156.

29. Skowronek, Tomasz. 2016. Las katyński. Gołuchów: Ośrodek Kultury Leśnej w Gołuchowie i Bogucki Wydawnictwo Naukowe.

30. Snopkiewicz, Jacek and Andrzej Zakrzewski. 1992. Decyzja: dokumenty Katynia. Warszawa: „Interpress".

31. Strzyżewski, Tomasz. 1977. Czarna księga cenzury PRL, vol. 1. London: Wydawnictwo Aneks.

32. Suchodolski, Bogdan. 1959. Mała Encyklopedia Powszechna PWN. Warszawa: Państwowe Wydawnictwo Naukowe.

33. Turlejska, Maria. 1953. Druga wojna światowa. In Historia Polski 1864-1945, ed. Żanna Kormanowa. Warszawa: Państwowe Zakłady Wydawnictw Szkolnych.

34. Wosik, Ewa. 1992. Katyń. Dokumenty ludobójstwa. Dokumenty i materiaty archiwalne pzekazane Polsce 14 października 1992r. Warszawa: Instytut Studiów Politycznych Polskiej Akademii Nauk.

35. Zieliński, Zbigniew. 2006. Przysposobienie Wojskowe Leśników jako element Obrony Narodowej. In $Z$ dziejów Lasów Państwowych i leśnictwa polskiego, vol.1, ed. Andrzej J. Szujecki. Warszawa: Centrum Informacyjne Lasów Państwowych: 523-546.

36. Zubkowicz, Rafał. 2017. Kadra nadleśnictw Dyrekcji Lasów Państwowych Okręgu Siedleckiego w latach 1938-1939. Studia i Materiaty Ośrodka Kultury Leśnej 16: 281-295.

\section{Legislation}

37. Regulation of the Minister of Agriculture and State Goods of August 11, 1926 on the duration of the preparatory service of candidates for the position of 1st category forest officials in the administration of state forests. [Journal of Laws of 1926, No. 85, item 479] (Rozporządzenie Ministra Rolnictwa $i$ Dóbr Państwowych z dnia 11 sierpnia 1926 r. o czasie trwania służby przygotowawczej kandydatów na stanowiska urzędników leśnych I kategorji w administracji lasów państwowych. [Dz.U. 1926, nr 85, poz. 479]). http://prawo.sejm.gov.pl/isap.nsf/download.xsp/WDU19260850479/O/D19260479.pdf. Accessed 5 April 2020.

38. Regulation of the Minister of Agriculture and State Goods of October 24, 1925 regarding the requirements for candidates for some positions of lower forest functionaries in state forest directorates and forest districts. [Journal of Laws of 1925, no. 115, item 819] (Rozporządzenie Ministra Rolnictwa i Dóbr Państwowych z dnia 24 października 1925 r. w sprawie ustalenia wymagań od kandydatów na niektóre stanowiska niższych funkcjonarjuszów leśnych w dyrekcjach lasów państwowych i nadleśnictwach. [Dz.U. 1925, nr 115, poz. 819]). http://prawo.sejm.gov.pl/isap.nsf/download.xsp/WDU19251150819/O/ D19250819.pdf. Accessed 5 April 2020.

39. Act on the state civil service of February 17, 1922 [Journal of Laws of 1922, No. 21, item 164] (Ustawa o państwowej służbie cywilnej z 17 lutego 1922 roku [Dz.U. 1922, nr 21, poz. 164]) http://prawo.sejm. gov.pl/isap.nsf/download.xsp/WDU19220210164/O/D19220164.pdf. Accessed 5 April 2020. 
40. Regulation of the Council of Ministers of January 24, 1925 regarding the inclusion of officers of lower managements of state forests and forest districts in individual salary groups. [Journal of Laws of 1925, No. 12, item 87] (Rozporządzenie Rady Ministrów z dnia 24 stycznia 1925 r. o zaliczeniu funkcjonariuszów niższych dyrekcji lasów państwowych i nadleśnictw do poszczególnych grup uposażenia. [Dz.U. 1925, nr 12, poz. 87]) http://prawo.sejm.gov.pl/isap.nsf/download.xsp/WDU19250120087/O/D1925 0087.pdf. Accessed 5 April 2020.

41. Regulation of the Council of Ministers of October 7, 1925 on the preparatory service and technical and forestry examination of candidates for the position of 1st category forest officials in the administration of state forests and the state forest protection service. [Journal of Laws of 1925, No. 110, item 786] (Rozporządzenie Rady Ministrów z dnia 7 października 1925 r. o służbie przygotowawczej i egzaminie techniczno-leśnym kandydatów na stanowiska urzędników leśnych I kategorii w administracji lasów państwowych oraz państwowej służbie ochrony lasów. [Dz.U. 1925, nr 110, poz. 786]) http://prawo .sejm.gov.p1/isap.nsf/download.xsp/WDU19251100786/O/D19250786.pdf. Accessed 5 April 2020.

42. Regulation of the Council of Ministers of May 13, 1927 on amendments and additions to the Regulation of the Council of Ministers of June 26, 1924 establishing a table of positions in state authorities and offices. [Journal of Laws of 1927, No. 56, item 493] (Rozporządzenie Rady Ministrów z dnia 13 maja 1927 r. w sprawie zmian i uzupełnień rozporządzenia Rady Ministrów z dnia 26 czerwca 1924 r. o ustanowieniu tabeli stanowisk we władzach i urzędach państwowych. [Dz.U. 1927, nr 56, poz. 493]. http://prawo.sejm.gov.pl/isap.nsf/download.xsp/WDU19270560493/O/D19270493.pdf. Accessed 5 April 2020.

43. Regulation of the Council of Ministers of 25 January 1928 on the preparatory service and examination of candidates for the first category of technical and forestry service in the administration of state forests and in the state forest protection service. [Journal of Laws of 1928, No. 17, item 145] (Rozporządzenie Rady Ministrów z dnia 25 stycznia 1928 r. o służbie przygotowawczej i egzaminie kandydatów na stanowiska I kategorji służby techniczno-leśnej w administracji lasów państwowych oraz w państwowej służbie ochrony lasów. [Dz.U. 1928, nr 17, poz. 145]). http://prawo.sejm.gov.pl/isap.nsf/download.xsp/ WDU19280170145/O/D19280145.pdf. Accessed 5 April 2020.

44. Regulation of the Council of Ministers of 19 March 1928 on the preparatory service and examination of candidates for the positions of the 3rd category of the state forest protection and technical service in the Directorates of State Forests and forest districts. [Journal of Laws of 1928, No. 46, item 451] (Rozporządzenie Rady Ministrów z dnia 19 marca 1928 r. o służbie przygotowawczej i egzaminie kandydatów na stanowiska III-ej kategorji państwowej służby leśnej ochronnej i technicznej w Dyrekcjach Lasów Państwowych i nadleśnictwach. [Dz. U. 1928, nr 46, poz. 451]). http://prawo.sejm.gov.pl/ isap.nsf/download.xsp/WDU19280460451/O/D19280451.pdf. Accessed 5 April 2020.

45. Regulation of the President of the Republic of Poland of 22 March 1928 regarding the amendment of certain provisions of the Act of February 17, 1922 on the State Civil Service. [Journal of Laws of 1928, No. 38, item 367] (Rozporządzenie Prezydenta Rzeczypospolitej z dnia 22 marca 1928 r. w sprawie zmiany niektórych postanowień ustawy z dnia 17 lutego 1922 r. o państwowej służbie cywilnej. [Dz. U. 1928, nr 38, poz. 367]). http://prawo.sejm.gov.pl/isap.nsf/download.xsp/WDU19280380367/O/D1928 0367.pdf. Accessed 5 April 2020.

46. Regulation of the Minister of Agriculture of 14 April 1928 on repealing the binding force of the Regulation of the Minister of Agriculture and State Goods of 24 October 1925 on determining the requirements for candidates for some positions of lower forest functionaries in state forest directorates and forest districts. [Journal of Laws of 1928, No. 51, item 492] (Rozporządzenie Ministra Rolnictwa z dnia 14 kwietnia 1928 r. o uchyleniu mocy obowiązującej rozporządzenia Ministra Rolnictwa i Dóbr Państwowych z dnia 24 października 1925 r. w sprawie ustalenia wymagań od kandydatów na niektóre stanowiska niższych funkcjonarjuszów leśnych w dyrekcjach lasów państwowych i nadleśnictwach. [Dz.U. 1928, nr 51, poz. 492]). http://prawo.sejm.gov.pl/isap.nsf/download.xsp/WDU19280510492/O/ D19280492.pdf. Accessed 5 April 2020.

47. Regulation of the Council of Ministers of January 20, 1934 establishing a table of positions in the administration of state forests. [Journal of Laws of 1934, No. 8, item 66] (Rozporządzenie Rady Ministrów z dnia 20 stycznia 1934 r. o ustanowieniu tabeli stanowisk w administracji lasów państwowych. [Dz.U. 1934, nr 8, poz. 66]). http://prawo.sejm.gov.pl/isap.nsf/download.xsp/WDU19340080066/O/ D19340066.pdf. Accessed 5 April 2020.

48. Regulation of the Council of Ministers of April 10, 1934 regarding supplementing the table of positions in the administration of state forests. [Journal of Laws of 1934, No. 36, item 329] (Rozporządzenie Rady Ministrów z dnia 10 kwietnia 1934 r. w sprawie uzupełnienia tabeli stanowisk w administracji 
lasów państwowych. [Dz. U. 1934, nr 36, poz. 329]). http://prawo.sejm.gov.pl/isap.nsf/download.xsp/ WDU19340360329/O/D19340329.pdf. Accessed 5 April 2020.

\section{Other}

49. Genocide Museum. The Armenian Genocide Museum-institute. www.genocide-museum.am. Retrieved 10 February 2020.

50. Main statistical Office of the Republic of Poland (Główny Urząd Statystyczny). Reports published at the website https://stat.gov.pl/. Accessed 7 January 2020.

Publisher's Note Springer Nature remains neutral with regard to jurisdictional claims in published maps and institutional affiliations.

\section{Affiliations}

\section{Dariusz J. Gwiazdowicz ${ }^{1}$ Aleksandra Matulewska² ${ }^{2}$}

Dariusz J. Gwiazdowicz

dariusz.gwiazdowicz@up.poznan.pl

1 Department of Forest Protection, Faculty of Forestry, Poznań University of Life Sciences, Collegium Maximum, Wojska Polskiego 28, 60-637 Poznan, Poland

2 Faculty of Modern Languages and Literatures, Adam Mickiewicz University, Collegium Novum, al. Niepodległości 4, Block A Room 107, 61-874, Poznan, Poland 